\title{
地震基盤までの地盤構造と地盤増幅度の地震規模依存性の関係 RELATIONSHIP BETWEEN GROUND STRUCTURE TO SEISMIC BEDROCK AND DEPENDENCY OF AMPLIFICATION FACTOR ON EARTHQUAKE MAGNITUDE
}

\author{
西川隼人*，宮島昌克** \\ Hayato NISHIKAWA and Masakatsu MIYAJIMA
}

\begin{abstract}
An effect of not only subsurface structure but also deep ground structure on an amplification factor depended on earthquake magnitude is investigated by using records of KiK-net observation sites where information of ground structure to seismic bedrock is already obtained. Relationship between moment magnitude $\left(M_{w}\right)$ of an earthquake and an amplification factor is examined at each observation site. The relation is not clear at observation sites with low fundamental frequency in transfer function. Since the transfer function at observation sites of thick sedimentary layer is amplified in broadband frequency range regardless of an earthquake magnitude, it is conceivable that the amplification factors at their sites are little dependent on earthquake magnitude.
\end{abstract}

Keywords : KiK-net, Amplification factor, Magnitude, Seismic bedrock, Transfer function KiK-net，地盤増幅度，地震規模，地震基盤，伝達関数

\section{1. はじめに}

地震動指標の地盤増幅度は地震動予測や地震八ザードマップにお いて重要な役割を果たすものであり、平均 $\mathrm{S}$ 波速度、表層地盤情報、 入力地震動と地盤増幅度の関係が評価されている ${ }^{1) ~ 9) 。 ま た 、 こ れ ~}$ らの研究と比較すると数は多くないが、地盤増幅度と地震規模の関 係を調べた研究がいくつか見られる ${ }^{10) ~ 13) 。 ~}$

紺野ら ${ }^{11)}$ や翠川ら ${ }^{12)}$ は横浜市の強震観測網の地震記録を分析し、 表層地盤の平均 $\mathrm{S}$ 波速度と最大地動加速度、最大地動速度などの地 盤増幅度 $(\mathrm{S}$ 波速度 $600 \mathrm{~m} / \mathrm{s}$ 程度の層を基準)の関係が地震規模によっ て変化することを示している。また、神田・武村 $\left.{ }^{13}\right)$ は関東地方を対 象に観測記録と距離減衰式による計測震度の差(相対震度)の M 依存 性の関係を調べており、M7.9 相当地震の相対震度と表層地盤の関係 を論じている。これらの研究では表層地盤と地盤増幅度の地震規模 依存性の関係を調べているが、地震の規模が大きくなると長周期成 分が卓越してくるので、強震動予測で対象となるような規模の大き な地震については表層地盤だけでなく地震基盤までのより深い地盤 構造の地盤増幅度への影響を調べる必要があると考えられる。

著者ら $\left.{ }^{14}\right)$ は地震基盤相当の層( $\mathrm{S}$ 波速度 $3 \mathrm{~km} / \mathrm{s}$ 程度の層)までの地 盤構造が明らかな KiK-net 観測点の地震記録を用い、地震基盤を基 準とした地盤増幅度の地震規模依存性を調べており、地震基盤から 表層地盤のサイト増幅特性の違いによる増幅度の地震規模依存性の 違いを明らかにしている。ただし、対象観測点で地震基盤までの深
度が $1 \mathrm{~km}$ 以上の観測点は 1 地点しかなく、堆積層の厚い地点におけ る地盤増幅度の地震規模依存性の評価が十分とは言い難い。

本論文では著者らの研究 ${ }^{14)}$ の対象観測点に地震基盤までの深度が $1 \sim 3 \mathrm{~km}$ の地震観測点を複数加えることにより、地震基盤までの深 度が様々な地点を対象に地盤構造が地盤増幅度の地震規模依存性に 及ぼす影響を評価する。検討においては著者らの研究で対象としな かった実効加速度についても地盤増幅度の地震規模依存性を調べる。 また、本論文では過去の研究で十分になされていない地震規模依存 性の要因の定量的な分析を、著者らの提案する地震動スペクトルと 地盤増幅度の関係式 ${ }^{15)}$ に基づいて行う。

\section{2. 解析条件}

\section{1 対象観測点}

本論文ではS波速度が $3 \mathrm{~km} / \mathrm{s}$ 前後の地震基盤相当の解放基盤面(以 降、基盤）を基準として地盤増幅度を評価するので、基盤までの地 盤定数が明らかな観測点を解析対象とする必要がある。そこでこれ

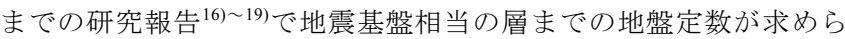
れているKiK-net観測点のうち、以下の条件を満たしている観測記録 が20以上ある18地点を解析対象観測点とした。

$\cdot M_{w} \geqq 4.0$ の地震の記録

・地盤の非線形化の影響を避けるために地表波の最大加速度(3成分 合成值)が $200 \mathrm{~cm} / \mathrm{s}^{2}$ 未満の記録

\footnotetext{
* 舞鶴工業高等専門学校 技術職員 ·博士 (工学)

Technical Stuff, Maizuru National College of Technology, Dr. Eng.

** 金沢大学理工研究域 教授.工博 

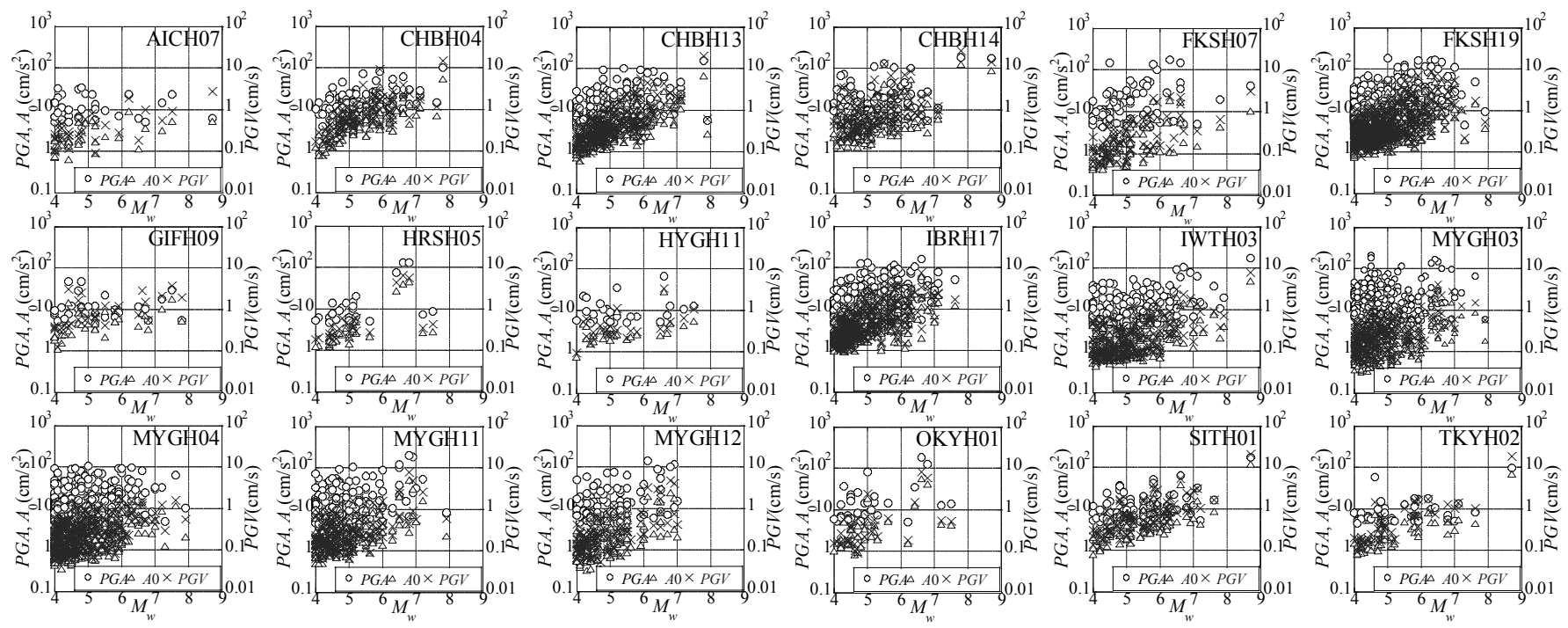

図 1 各観測点の $M_{w}$ と $P G A 、 A_{0} 、 P G V$ の関係

表 1 対象とした KiK-net 観測点の情報

\begin{tabular}{|c|c|c|c|c|l|c|c|}
\hline $\begin{array}{c}\text { 観測点 } \\
\text { 镍測点名 }\end{array}$ & $\begin{array}{c}\text { 緯度 } \\
\left({ }^{\circ}\right)\end{array}$ & $\begin{array}{c}\text { 経度 } \\
\left({ }^{\circ}\right)\end{array}$ & $M w$ & 期間 & $\begin{array}{c}\text { 設置深度 } \\
(\mathrm{m})\end{array}$ & データ数 \\
\hline AICH07 & 旭 & 35.2194 & 137.4039 & $4.0-8.7$ & $1999 / 1 / 28-2011 / 3 / 15$ & 201 & 33 \\
\hline CHBH04 & 下総 & 35.7966 & 140.0206 & $4.0-7.8$ & $2003 / 4 / 8-2011 / 12 / 3$ & 2300 & 101 \\
\hline CHBH13 & 成田 & 35.8307 & 140.2980 & $4.0-7.9$ & $2003 / 1 / 9-2011 / 12 / 22$ & 1300 & 275 \\
\hline CHBH14 & 銚子中 & 35.7342 & 140.8230 & $4.0-8.7$ & $2003 / 7 / 17-2011 / 12 / 26$ & 525 & 123 \\
\hline FKSH07 & 檜枝岐 & 37.0103 & 139.3755 & $4.0-8.7$ & $2000 / 7 / 21-2011 / 11 / 28$ & 200 & 78 \\
\hline FKSH19 & 都路 & 37.4703 & 140.7227 & $4.0-7.9$ & $2000 / 8 / 19-2011 / 12 / 22$ & 100 & 512 \\
\hline GIFH09 & 羽島 & 35.2768 & 136.7002 & $4.0-7.8$ & $1999 / 11 / 7-2011 / 8 / 1$ & 1508 & 31 \\
\hline HRSH05 & 神辺 & 34.5566 & 133.4179 & $4.0-7.5$ & $1999 / 10 / 30-2011 / 11 / 25$ & 200 & 26 \\
\hline HYGH11 & 山東 & 35.2925 & 134.9071 & $4.0-7.5$ & $1999 / 3 / 16-2011 / 11 / 21$ & 200 & 25 \\
\hline IBRH17 & 霞ヶ浦 & 36.0864 & 140.3140 & $4.0-7.6$ & $2003 / 4 / 25-2011 / 12 / 31$ & 510 & 327 \\
\hline IWTH03 & 岩泉 & 39.8020 & 141.6520 & $4.0-8.7$ & $2000 / 7 / 30-2011 / 12 / 10$ & 100 & 219 \\
\hline MYGH03 & 唐桑 & 38.9207 & 141.6377 & $4.0-8.7$ & $2001 / 4 / 3-2011 / 12 / 30$ & 117 & 272 \\
\hline MYGH04 & 東和 & 38.7860 & 141.3254 & $4.0-7.9$ & $2000 / 9 / 17-2011 / 12 / 30$ & 100 & 339 \\
\hline MYGH11 & 河北 & 38.5158 & 141.3421 & $4.0-7.9$ & $2001 / 2 / 5-2011 / 3 / 10$ & 207 & 189 \\
\hline MYGH12 & 志津川 & 38.6416 & 141.4428 & $4.0-7.0$ & $2001 / 4 / 5-2011 / 3 / 10$ & 103 & 119 \\
\hline OKYH01 & 玉野 & 34.5070 & 133.8905 & $4.0-7.5$ & $1999 / 7 / 16-2011 / 11 / 25$ & 201 & 34 \\
\hline SITH01 & 岩槻 & 35.9290 & 139.7349 & $4.0-8.7$ & $2008 / 4 / 4-2011 / 12 / 3$ & 3510 & 92 \\
\hline TKYH02 & 府中 & 35.6539 & 139.4704 & $4.0-8.7$ & $2008 / 4 / 4-2011 / 12 / 10$ & 2753 & 48 \\
\hline
\end{tabular}

・地表波の最大加速度(3成分合成值)が $5 \mathrm{~cm} / \mathrm{s}^{2}$ 以上の記録

$M_{w}$ はF-net ${ }^{20)}$ による值を用いた。図1に対象としたKiK-net観測点の $M_{w}$ と地震動指標の関係、表 1 に対象観測点の記録の諸元、図 2 に対象観 測点のS波速度構造を示す。地盤定数は羽島は日本原子力発電など の報告 ${ }^{18)}$ 、下総、岩槻、府中は木下・大池の研究 ${ }^{19)} を$ 元に設定し、 その他の観測点は原子力安全基盤機構 ${ }^{16), 17)}$ による值を用いた。各観 測点の減衰定数または $Q s$ 值は日本原子力発電などと原子力安全基 盤機構では各層ごとに与えられているのに対し、木下・大池は層に よらず一定の值を与えていて、 $f=0.5 \sim 2 \mathrm{~Hz}$ では $Q s か ゙ 50 f 、 2 \sim 16 \mathrm{~Hz}$ で は110としている。なお、本論文では $Q s=50 f$ が $0.5 \mathrm{~Hz}$ 以下、 $Q s=110$ が $16 \mathrm{~Hz}$ 以上でも成り立つと仮定し解析を行った。

\section{2 フーリエスペクトルと S 波伝達関数}

対象観測点の地表と地中の加速度フーリエスペクトルとそのスペ クトル比の特徵を今回新たに追加した観測点を例に調べる。図 3 に $M_{w}$ ごとの地表と地中の加速度フーリエスペクトル、眓 4 に $M_{w}$ ごと のフーリエスペクトル比を示す。図 3、4 で対象とした観測記録の最 大加速度は $10 \sim 35 \mathrm{~cm} / \mathrm{s}^{2}$ であり、 $M_{w} 6$ 未満の記録のフーリエスペク トルは波形の $\mathrm{S}$ 波到達から 5 秒間を切り出し、 $M_{w} 6$ 以上の場合は 10 秒間を切り出して求めた。また、バンド幅 $0.1 \mathrm{~Hz}$ の Parzen window
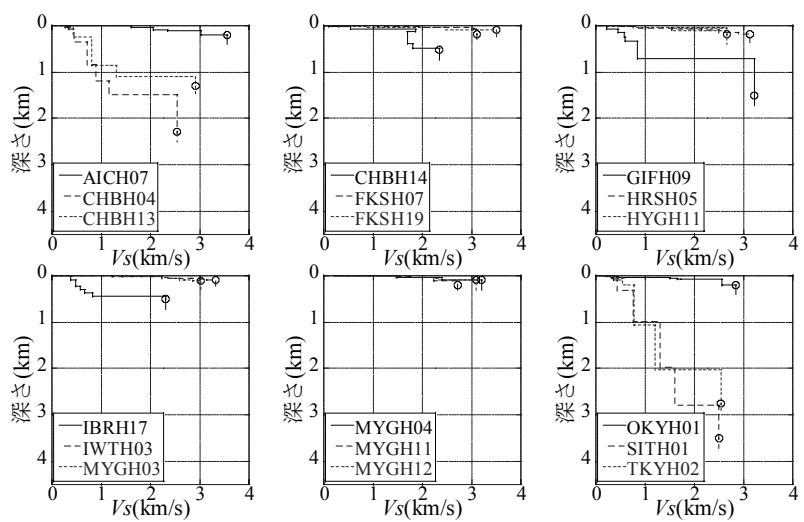

図 $2 \mathrm{~S}$ 波速度構造 $(\mathrm{O}$ は地中地震計位置 $)$
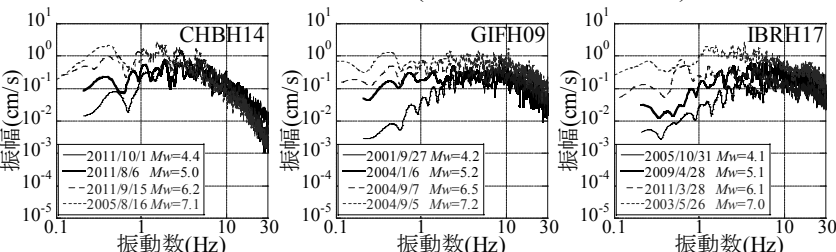

(a) 地中
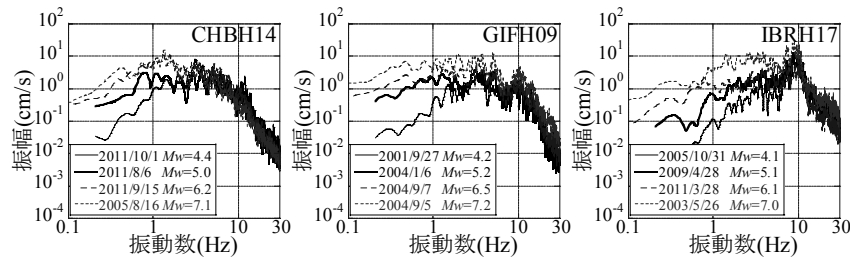

(b) 地表

図 3 加速度フーリエスペクトル

によってスペクトルを平滑化した。図 3 を見ると $M_{w}$ が大きくなる ほど低振動数側の振幅が大きくなっていることが分かる。一方、図 4 のフーリエスペクトル比を見ると $M_{w}$ によって 1 次固有振動数やス ペクトル形状に大きな違いはない。

図 5 に本論文で追加した 6 観測点を対象に文献 ${ }^{16) ~ 19)}$ の地盤定数 を用いて重複反射理論によって求めた $\mathrm{S}$ 波理論伝達関数とフーリエ スペクトル比平均值を示す。理論伝達関数は SH 波が鉛直入射した 場合の值であり、基盤での入射波十反射波 $(\mathrm{E}+\mathrm{F})$ に対する応答である。 各観測点のスペクトル比平均值は常用対数值の算術平均值と平均值 

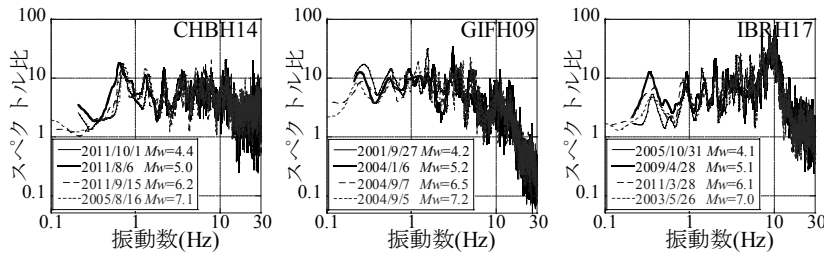

図
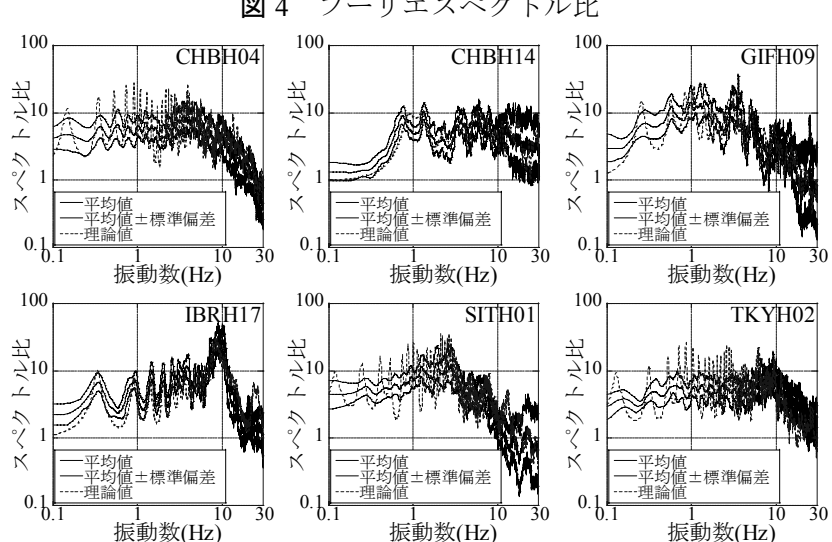

図 $5 \mathrm{~S}$ 波理論伝達関数 $(\mathrm{E}+\mathrm{F})$ とフーリエスペクトル比(平均值)
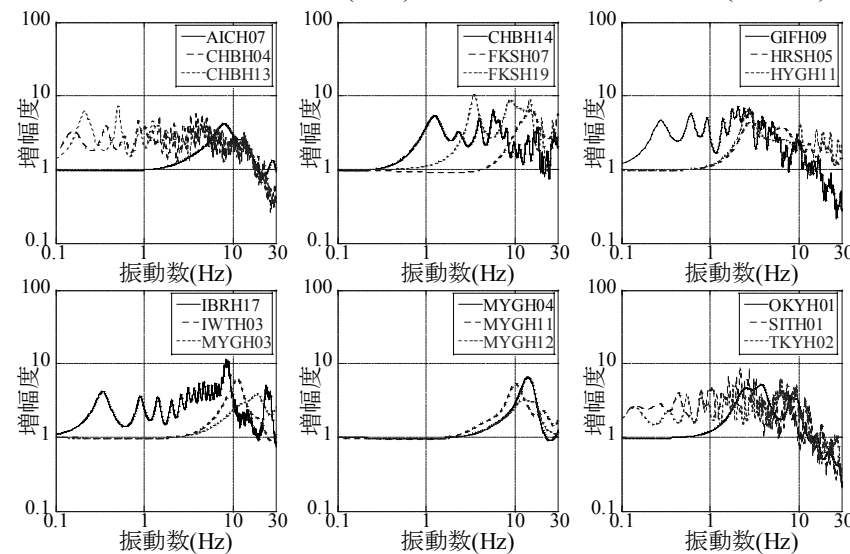

図 $6 \mathrm{~S}$ 波理論伝達関数 $(2 \mathrm{E})$

に標準偏差を考慮した值である。フーリエスペクトル比は $M w 6$ 以上 の地震で観測された地表と地中の地震波形記録において $\mathrm{S}$ 波到達か ら 10 秒間を切り出して求めた。図 5 から対象観測点の理論伝達関数 がスペクトル比と概㸚対応していることが分かる。

図 6 に基盤への入射波に対する $\mathrm{S}$ 波理論伝達関数(2E)を示す。図 6 を見ると地震計設置深度が $100 \sim 200 \mathrm{~m}$ 程度の観測点の伝達関数の 1 次固有振動数が $1 \mathrm{~Hz}$ 以上になっている。設置深度が $500 \mathrm{~m}$ 以上の 観測点の伝達関数を見ると、多くの観測点の 1 次固有振動数が $1 \mathrm{~Hz}$ 以下であり、低振動数領域まで増幅されていることが分かる。

\section{3. 地盤増幅度の評価と地震規模依存性との関係 3.1 地盤増幅度の評価}

観測記録による最大地動加速度、速度の地盤増幅度はそれぞれ地 表と基盤の加速度、あるいは速度時刻歴波形の水平 2 成分最大值の 大きい方の值の比と定義した。ただし、加速度、速度波形の最大振 幅が後続波の場合は S 波到達から破壊継続時間を加えた区間での最 大值を最大振幅として用いた。破壊継続時間は川上らの論文 ${ }^{21)}$ の式 を用いて計算した。速度時刻歴波形は加速度波形をフーリエ变換を 利用して積分寸ることによって求めた。なお、積分の際には 0.1
$20 \mathrm{~Hz}$ でフラットであり、両端にコサインテーパーを施したバンドパ スフィルターをかけている。基盤の地震波形は地表の地震波形と地 盤定数を用い、重複反射理論に基づく剥ぎ取り解析によって計算し た。実効加速度は水平 2 成分と上下動の 3 成分によって評価するも のであるが、両者の計算值に大きな差がないことを確認した上で地 表、基盤ともに水平 2 成分により評価した。

\section{3. $2 M_{W}$ と地盤増幅度の関係}

図 7 に対象観測点の $M_{w}$ と地盤増幅度の関係の一例を示す。図 7(a) は $\mathrm{S}$ 波伝達関数 $(2 \mathrm{E})$ の 1 次固有振動数が $10 \mathrm{~Hz}$ 以上、図 7(b)は 1 次固 有振動数が $1 \sim 10 \mathrm{~Hz}$ 、図 7(c)は $1 \mathrm{~Hz}$ 以下の地点である。凡例の $F_{A}$ 、 $F_{A 0} 、 F_{V}$ はそれぞれ最大地動加速度 $P G A$ 、実効加速度 $A_{0}$ 、最大地動 速度 $P G V$ の地盤増幅度に対応する。

図 7(a)を見ると、いずれの観測点の $F_{A} 、 F_{A 0} 、 F_{V}$ も $M_{w}$ の増大に伴 って低下しており、F $F_{A 0}$ と $F_{V}$ の低下が顕著である。図 7(b)を見ると、 AICH07 は図 7(a)の観測点と同じ傾向を示すが、 1 次固有振動数が 1 〜3Hz の HRSH05、HYGH11、CHBH14 では $F_{A} 、 F_{A 0}$ の $M_{w}$ による変 化が小さい。 $F_{V}$ は $M_{w}$ が大きくなるほど低下しているが、図 7(a)に 示寸観測点に比べると低下の割合は緩やかである。図 7(c)の 1 次固 有振動数が $1 \mathrm{~Hz}$ 以下の観測点を見ると、いずれの観測点も $F_{A}$ が $M_{w}=4 \sim 6$ の範囲で大きくなる傾向にある。また、 4 つの観測点とも $F_{A 0}$ と $F_{V}$ は $M_{w}$ によってあまり変化していない。

以上、いくつかの観測点を例に $M_{w}$ と地盤増幅度の関係を見たが、 同一の $M_{w}$ でも地盤増幅度にばらつきがあり、両者の関係が不明瞭 である。地盤増幅度の理論的な検討は次章で行うものとし、平均的 な $M_{w}$ と地盤増幅度の関係を調べるために、 $M_{w}$ の 1 次式で表される 以下の関係式を求めた。

$$
\log _{10} F_{i}=C_{1}^{i} M_{w}+C_{2}^{i}
$$

ここで $F_{i}$ は地盤増幅度、 $C_{1}{ }^{i} 、 C_{2}{ }^{i}$ は回帰係数、添え字 $i$ は地震動指標 に対応するものであり、 $P G A$ の場合は $A 、 A_{0}$ の場合は $A_{0} 、 P G V$ の場 合は $V$ である。式(1)は各観測点に対し回帰分析で求める。

図 8 に解析対象とした全観測点の $M_{w}$ と式(1)によって求めた地盤 増幅度 $F_{i}$ の関係を示す。図 8 は $\mathrm{S}$ 波伝達関数 $(2 \mathrm{E})$ の 1 次固有振動数 が高い順に並べている。1 次固有振動数が $7.82 \sim 18.52 \mathrm{~Hz}$ (AICH07 ～MYGH03）の観測点の地盤増幅度を見ると、いずれも $M_{w}$ が大き くなるほど増幅度が低下しており、 $F_{A 0} 、 F_{V}$ の低下が顥著である。1 次固有振動数が $1.23 \sim 3.42 \mathrm{~Hz}$ の観測点では $\mathrm{AICH} 07 \sim \mathrm{MYGH} 03$ と比 較すると増幅度の低下が緩やかになっているものが多く、中には $F_{A}$ あるいは $F_{A 0}$ が $M_{w}$ の増大に伴い大きくなっている観測点も見られる。 続いて、 1 次固有振動数が $1 \mathrm{~Hz}$ 以下の観測点を見ると、 $F_{A}$ はいずれ の観測点も $M_{w}$ が大きくなるほど、緩やかに増加している。 $F_{A 0}$ と $F_{V}$ はIBRH17、TKYH02 では $M_{w}$ の増大に伴い緩やかに低下しているが、 その他の観測点は増幅度が $M_{w}$ によってほとんど変化しないか、緩 やかに大きくなる傾向にある。

以上の考察から $F_{A}$ は $M_{w}$ の増大に伴う低下が小さい、あるいは緩 やかに増大寸る傾向が見られた。 $F_{A 0}$ と $F_{V}$ は $M_{w}$ が大きくなるほど 低下寸る傾向にあるが、その状況は $\mathrm{S}$ 波伝達関数の 1 次固有振動数 によって大きく異なる。伝達関数の 1 次固有振動数が $1 \mathrm{~Hz}$ 以下の観 測点では $M_{w}$ による $F_{A 0} 、 F_{V}$ の顕著な低下は見られず、 $M_{w}$ 依存性が 明瞭でない。 

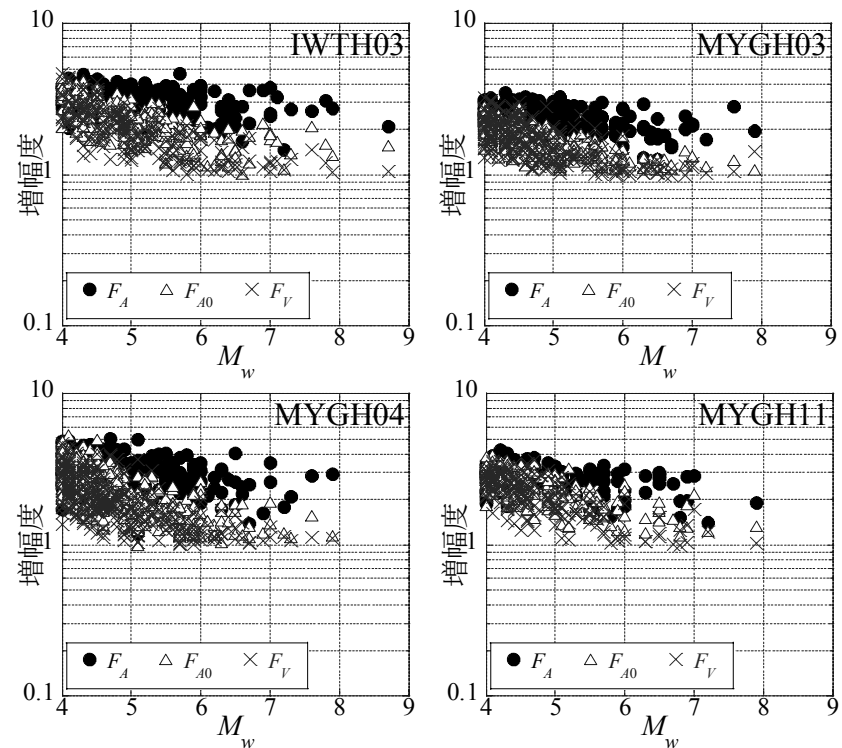

(a) $10 \mathrm{~Hz}$ 以上
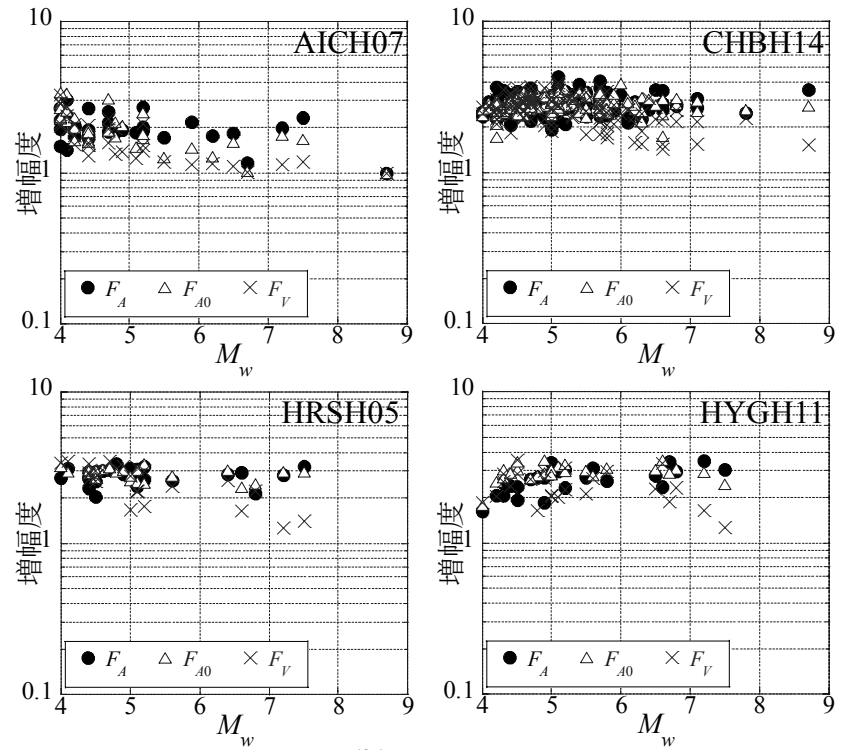

(b) $1 \sim 10 \mathrm{~Hz}$
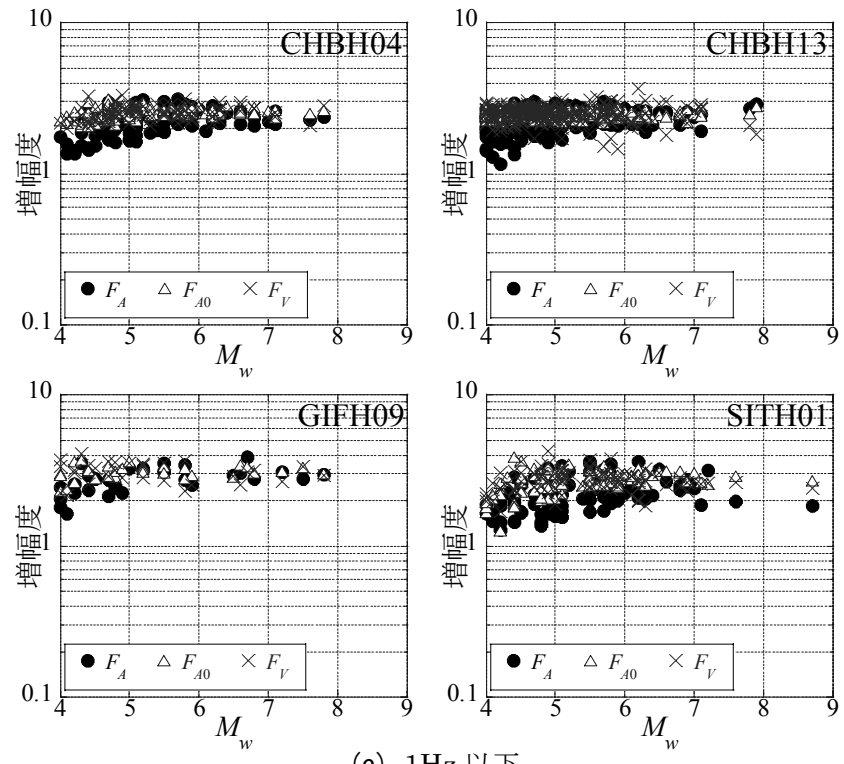

(c) $1 \mathrm{~Hz}$ 以下

図 $7 M_{w}$ と地盤増幅度の関倸
4. 地震動スペクトルと地盤増幅度の関係式に基づく増幅度の $M_{w}$ 依存性の考察

4.1 地震動スペクトルと地盤増幅度の関係式

3 章で示したように $\mathrm{S}$ 波伝達関数の 1 次固有振動数によって地盤 増幅度の地震規模依存性が大きく異なり、依存の様相は地震動指標 によって異なる。既往研究で指摘されているように、地震の規模に よる地震動スペクトルの変化が地盤増幅度の地震規模依存性の要因 と考えられることから、S 波伝達関数による地震規模依存性の違い を調べるためには 1 次固有振動数だけでなく、伝達関数全体の地盤 増幅度への影響を評価する必要があると考えられる。そこで本章で は著者ら ${ }^{15)}$ の提案している地震動スペクトルと地盤増幅度の関係式 に基づき、 $\mathrm{S}$ 波伝達関数による地震規模依存性の違いを考察する。 著者ら ${ }^{15)}$ はパーセバルの定理と極值理論を元に式(2)に示寸地盤増 幅度と地震動スペクトルの関係式を導いている。

$$
F_{i}=\frac{A_{s i}}{A_{b i}} \fallingdotseq \sqrt{\frac{\int_{-\infty}^{\infty} F_{s i}(f)^{2} d f}{\int_{-\infty}^{\infty} F_{b i}(f)^{2} d f}}=\sqrt{\frac{\int_{-\infty}^{\infty} G(f)^{2} F_{b i}(f)^{2} d f}{\int_{-\infty}^{\infty} F_{b i}(f)^{2} d f}}
$$

ここで $F_{i}$ は地盤増幅度、 $A_{s i}$ は地表波の最大振幅、 $A_{b i}$ は解放基盤の 地震波の最大振幅、 $F_{s i}(f)$ は地表波のフーリエスペクトルであり、S 波伝達関数 $G(f)$ と基盤波のフーリエスペクトル $F_{b i}(f)$ の積である。著 者らは先の研究 ${ }^{14)}$ で今回対象とする 12 地点に対して、地震観測記 録を用い式(2)の右辺と左辺を計算し、同式の適用性を確認している。 図 9 に既往研究 ${ }^{14)}$ で求めた式(2)の右辺と左辺の関係を $F_{A} 、 F_{V}$ につ いて示す。図 9 の横軸計算值が式(2)の右辺、縦軸観測值が左辺に対 応する。また、図右上の相関係数は計算值と観測值の常用対数值の 相関係数である。図から分かるようにばらつきがあるものの、式(2) の右辺と左辺が対応していることから、本論文でも式(2)に基づき検 討を進める。

\section{4. $2 M_{w}$ と地震動スペクトルの積分値、地盤増幅度の関係}

本節では式(2)を用い $M_{w}$ による地震動スペクトルと地盤増幅度の 変化を考察する。その中で式(2)から明らかなように地盤増幅度は地 震動スペクトルの積分值によって決まるので、 $M_{w}$ とスペクトル積分 值の関係を調べる。また、 $\mathrm{S}$ 波伝達関数による地盤増幅度の違いを 調べるために特徵の異なる 3 観測点(MYGH11、HRSH05、SITH01) の伝達関数を用いるが、純粋に伝達関数の地盤増幅度への影響を評 価するために、基盤スペクトルは同一のものを用いる。基盤は地震 波発生層とし、3 観測点の伝達関数には基盤と地中地震計設置地点 のインピーダンスの違いを考慮するため $\sqrt{\left(\rho V_{S}\right) /\left(\rho_{r} V_{r S}\right)}$ を乗じた。 ここで $\rho$ と $V_{S}$ は地震発生層の密度と $\mathrm{S}$ 波速度であり、それぞれ $2.7 \mathrm{~g} / \mathrm{cm}^{3} 、 3.4 \mathrm{~km} / \mathrm{s}$ とした。 $\rho_{r}$ と $V_{r S}$ は地中地震計設置地点の媒質の 密度と $\mathrm{S}$ 波速度である。

基盤波の加速度フーリエスペクトル $F_{b A}(f)$ は以下の式 ${ }^{22)}$ で表され るものとする。

$$
F_{b A}(f)=S(f) P(f)
$$

$S(f)$ は震源特性、 $P(f)$ は伝播経路特性であり、式(4)、(5)で表される。

$$
\begin{gathered}
S(f)=M_{0} \frac{R_{\theta \varphi} F_{S} P_{R T I T N}}{4 \pi \rho V_{S}^{3}} \frac{(2 \pi f)^{2}}{1+f^{2} / f_{c}^{2}} \frac{1}{\sqrt{1+f^{2} / f_{\max }^{2}}} \\
P(f)=\frac{1}{R} \exp \left(-\frac{\pi f R}{Q_{S} V_{S}}\right)
\end{gathered}
$$

式(4)の $M_{0}$ は地震モーメント $($ dyne $\cdot \mathrm{cm})$ であり、以下の $M_{w}$ との関 

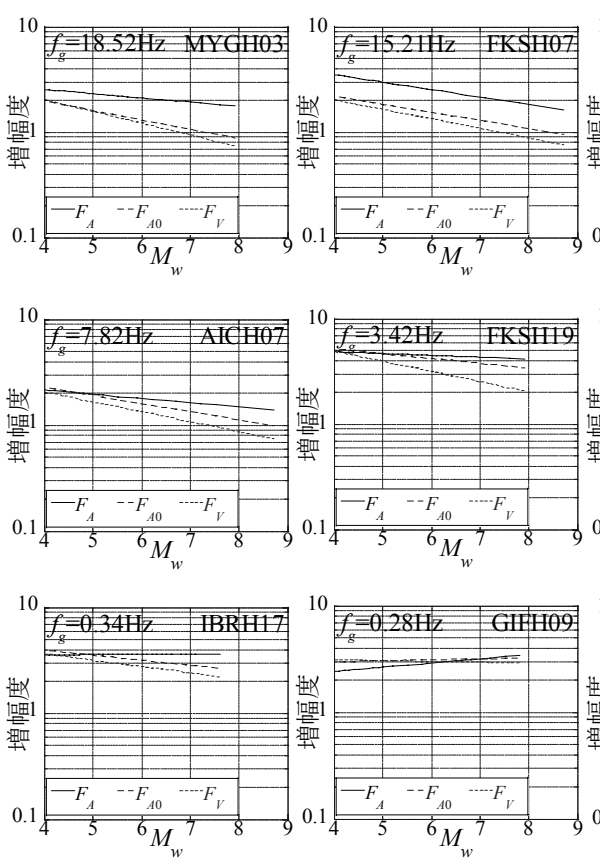

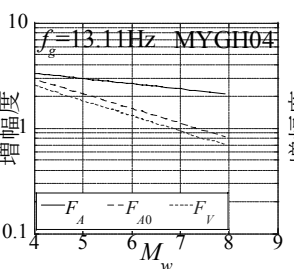

(a) $f_{g}=10.01 \sim 18.52 \mathrm{~Hz}$
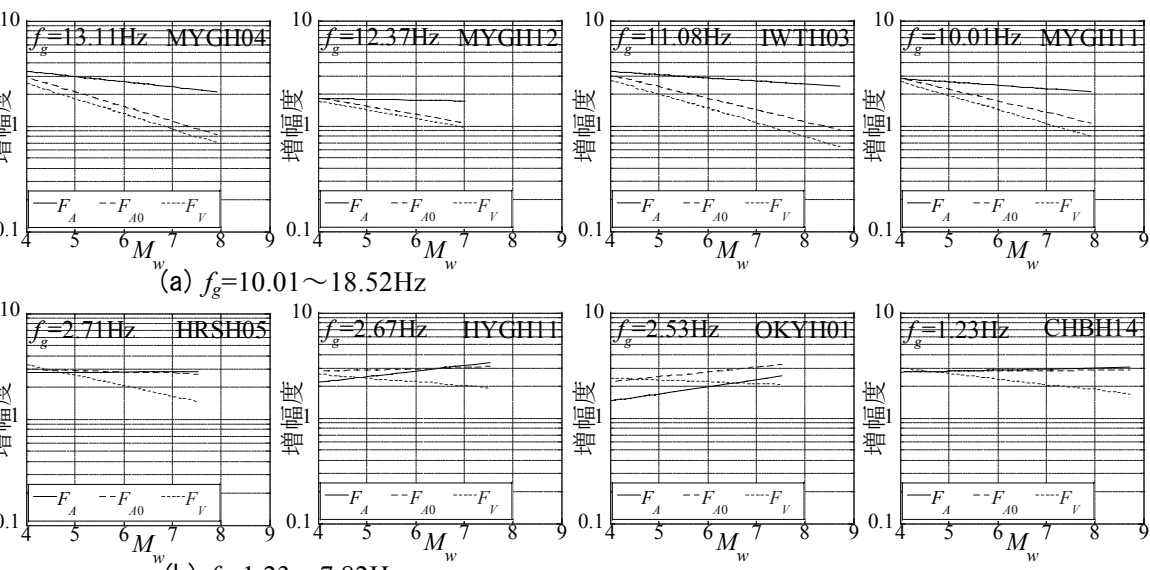

(b) $f_{g}=1.23 \sim 7.82 \mathrm{~Hz}$
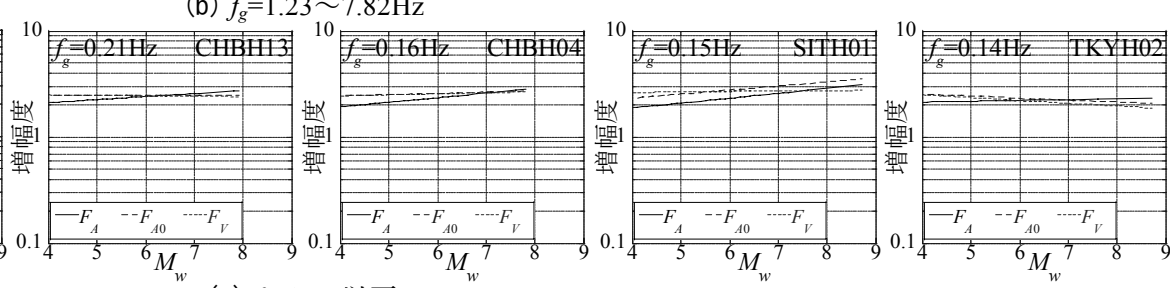

(c) $f_{g}=1 \mathrm{~Hz}$ 以下

図 $8 M_{w}$ と式(1)により計算した地盤増幅度 $F_{i}$ の関係

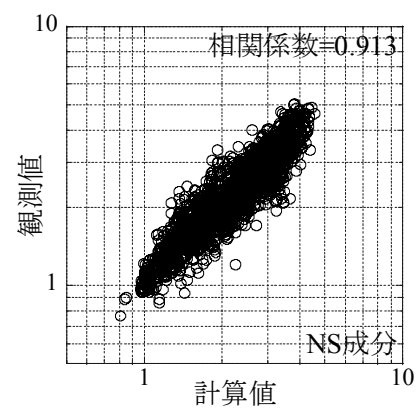

(a) 加速度 $A$
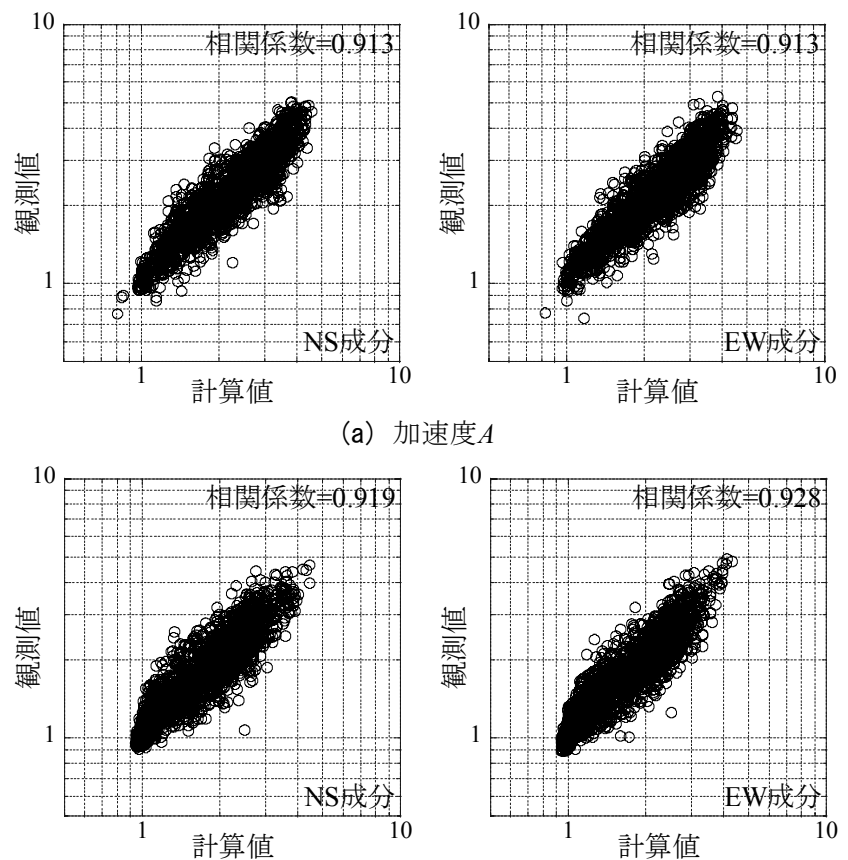

(b) 速度 $V$

図9 式(2)の右辺(計算値)と左辺(観測値)の対応 ${ }^{14)}$

係式 ${ }^{23)}$ によって求める。

$$
M_{0}=10^{\left(1.5 M_{w}+16.1\right)}
$$

$R_{\theta \varphi}$ はラディエーションパターン係数、 $F_{S}$ は自由地表面の増幅効果を 表す係数、 $P_{\text {RTITN }}$ はエネルギー分配係数である。 $R_{\theta \varphi}$ は全方位の平均 值である $0.63^{24)} 、 F_{S}$ は2、P $P_{R T T N}$ は 0.71 とした。 $f_{c}$ はコーナー振動数 $(\mathrm{Hz}) 、$ $f_{\max }$ は高域遮断振動数 $(\mathrm{Hz})$ であり、 $M_{0}$ をパラメータとする以下の 経験式 ${ }^{25)}$,26)から計算した。

$$
\begin{aligned}
& f_{c}=10^{\left\{\left(23.38-\log M_{0}\right) / 3\right\}} \\
& f_{\max }=7.31 \times 10^{3} \times M_{0}^{-0.12}
\end{aligned}
$$

式(5)のRは震源距離、 $Q_{s}$ はS 波の減衰の程度を表すパラメータである。
以降の計算において式(5)のRは $50 \mathrm{~km} と し 、 Q_{s}$ は佐藤による $Q_{s}=40 f$ の 関係式 ${ }^{27)}$ を用いた。

基盤波の速度フーリエスペクトル $F_{b V}(f)$ は $F_{b A}(f)$ を角振動数 $(2 \pi f)$ で 除することで得られる。また、実効加速度を対象とする場合の基盤 波のフーリエスペクトル $F_{b A 0}(f)$ として $F_{b A}(f)$ に震度算出の際に用いる フィルター28)を乗じたものを用いた。

図 10 に $M_{w}=4 、 5.5 、 7$ の場合の式 $(3)$ にる $F_{b i}(f)$ と $F_{s i}(f)$ 、図 11 に 式(2)の $F_{b i}(f)^{2}$ と $F_{s i}(f)^{2}$ の積分值、図 12 に $M_{w}$ と式(2) (8)によって求 めた地盤増幅度の関係を示す。なお、 $F_{b i}(f)^{2}$ と $F_{s i}(f)^{2}$ の積分值として $0 \sim 50 \mathrm{~Hz}$ を対象とした台形公式による積分值を用いた。

まず、 $F_{b A}(f)$ を見ると $M_{w}$ の増大に伴い低振動数の振幅が大きくな つている。 $F_{b A 0}(f)$ は $M_{w}=5.5 、 7$ の場合、震度算出の際のフィルター のピーク振動数付近 $(0.5 \sim 1 \mathrm{~Hz})$ で $F_{b A 0}(f)$ にピークが見られる。 $F_{b V}(f)$ は $F_{b A}(f) 、 F_{b A 0}(f)$ に比べて、 $M_{w}$ の増大に伴うピーク振幅の移動が顕著 である。 $F_{s i}(f)$ を見ると MYGH11 は S 波伝達関数の 1 次固有振動数 が $10 \mathrm{~Hz}$ にあるので、 $M_{w}$ が大きくなるほど $F_{s i}(f)$ の $10 \mathrm{~Hz}$ での振幅が 相対的に小さくなっており、 $F_{s v}(f)$ でその傾向が影著である。一方、 SITH01の S 波伝達関数では低振動数から高振動数まで増幅が見ら れることから、多くの振動数で $F_{s i}(f)$ が $F_{b i}(f)$ の振幅を上回っている。 HRSH05 は $2 つ の$ 観測点の中間的な特徵を示している。

続いて、図 11 の $F_{b i}(f)^{2} 、 F_{s i}(f)^{2}$ の積分值を見ると、加速度はいず れの観測点も $F_{b i}(f)^{2} 、 F_{s i}(f)^{2}$ の積分值の相対的な関係が $M_{w}$ によって あまり変化しない。実効加速度の場合は加速度に比べて観測点によ る違いが大きく、MYGH11 は $M_{w}$ が大きくなると両積分值の差が小 さくなっているが、HRSH05 と SITH01 は積分值の差にあまり違い は見られない。速度では観測点による違いがさらに顕著になり、 SITH01 は $M_{w}$ によって積分值の相対関係があまり変化しないのに対 し、MYGH11 と HRSH05 は $M_{w}$ が大きくなるにつれて積分值の差が 小さくなっている。

図 12 の $M_{w}$ と地盤増幅度の関係は図 11 の積分值の相対関係に対 応しており、 $F_{A} 、 F_{A 0} 、 F_{V}$ の順に $M_{w}$ による地盤増幅度の変化が大き 

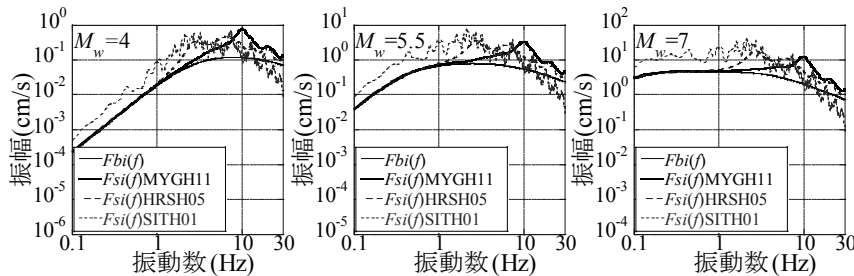

(a) 加速度 $A$
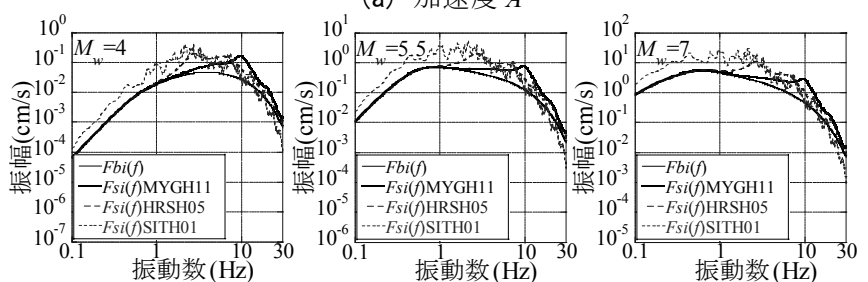

(b) 実効加速度 $A_{0}$
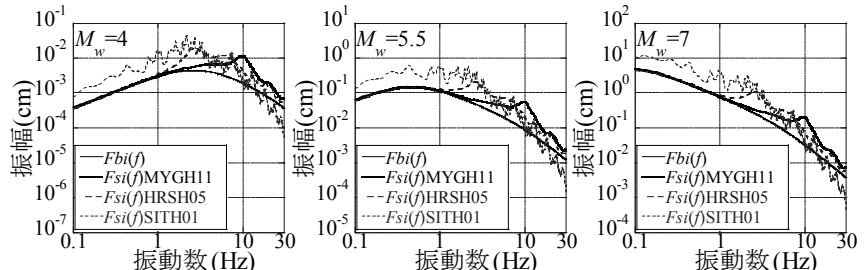

(c) 速度 $V$

図 $10 \quad F b i(f)$ と $F s i(f)$

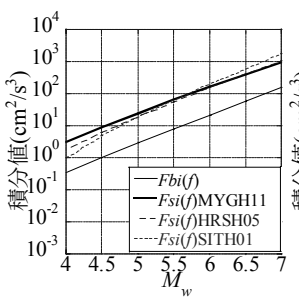

(a) 加速度 $A$

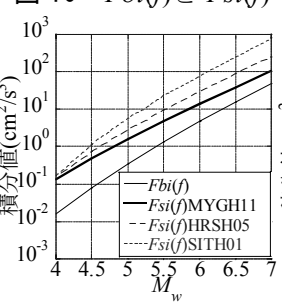

(b) 実効加速度 $A_{0}$

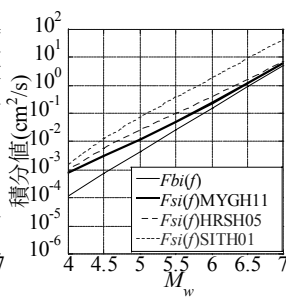

(c) 速度 $V$
図11式(2)の $F_{b i}(f)^{2}$ と $F_{s i}(f)^{2}$ の積分值

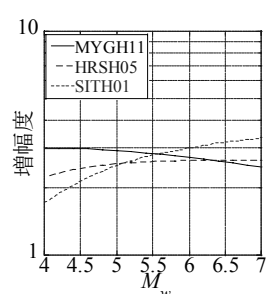

(a) 加速度 $A$

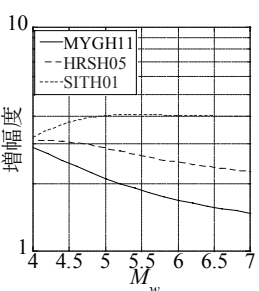

(b) 実効加速度 $A_{0}$

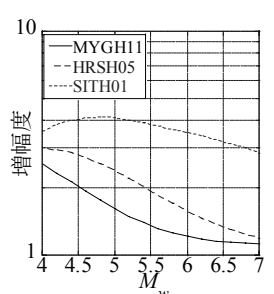

(c) 速度 $V$
図12 式(2)による地盤増幅度

くなり、 $F_{V}$ が最も地震規模依存性が強い。また、観測点による違い も $F_{V}$ が最も大きく、 $\mathrm{S}$ 波伝達関数によって $M_{w}$ と $F_{V}$ の関係が大きく 異なる。 $F_{V}$ の強い地震規模依存性は $M_{w}$ による $F_{b V}(f)$ のピーク振幅の 移動に起因しており、S 波伝達関数と $F_{b r}(f)$ のピーク振動数が近い場 合、F $F_{V}$ が大きくなりやすい。しかし、MYGH11、HRSH05 のように 伝達関数において増幅度が大きい振動数領域が限られる場合は伝達 関数と $F_{b r}(f)$ のピーク振動数が離れると増幅度が急激に低下寸る。 一方、SITH01 の $\mathrm{S}$ 波伝達関数は 1 次固有振動数の $0.15 \mathrm{~Hz}$ 付近まで 増幅が見られるため、 $M_{w}$ の大小によらず広い振動数領域で $F_{b r}(f)$ が 増幅される。その結果、SITH01 は $F_{b i}(f)^{2}$ と $F_{s i}(f)^{2}$ の積分值の相対関 係が $M_{w}$ に依存せず、MYGH11、HRSH05 と比較して、 $M_{w}$ の増大に よる $F_{V}$ の低下が小さい。

SITH01 のように堆積層の厚い地点では伝達関数において $0.1 〜$
$0.3 \mathrm{~Hz}$ 付近でも増幅が見られるため、 $M_{w}$ が大きくなっても $F_{V}$ があま り低下せず、また $F_{A} 、 F_{A}$ も大きな值になる可能性がある。強震動 予測においては $M_{w}$ が大きな地震での地盤増幅度の評価が必要とな ることから、表層地盤のみならず地震基盤相当の層までの地盤構造 が地盤増幅度に及ぼす影響を考慮することが必要不可欠であると考 えられる。

\section{5. まとめ}

本論文では地震基盤相当の層までの地盤構造が明らかな KiK-net 観測点 18 地点の地震観測記録を用い、表層地盤のみならず地震基盤 までの地盤構造が地盤増幅度の地震規模依存性に及ぼす影響を調心゙ た。以下に本論文で得られた知見をまとめる。

(1) 各観測点の $M_{w}$ と地盤増幅度の関係を調べた結果、 $F_{A}$ は $M_{w}$ に対 寸る依存性が明瞭でないが、 $F_{A 0} 、 F_{V}$ の $M_{w}$ 依存性は $\mathrm{S}$ 波伝達関 数 $(2 \mathrm{E})$ の 1 次固有振動数によって大きく異なり、1 次固有振動数 が $1 \mathrm{~Hz}$ 以下の観測点では $F_{A 0}$ と $F_{V}$ が $M_{w}$ によってあまり変化し なかった。

（2）地震動スペクトルの積分值による地盤増幅度評価式に基づき、S 波伝達関数が地盤増幅度の地震規模依存性に及ぼす影響を考察 した。その結果、地震規模依存性は $V 、 A_{0} 、 A$ の順に大きく、伝 達関数による違いも $V$ が最も大きくなった。これは $V$ 基盤波 のスペクトルが $M_{w}$ によって大きく変化することに起因する。

（3）堆積層が厚い地点では低振動数まで地震動が増幅されるため、 地表波スペクトルと基盤波スペクトルの相対関係が $M_{w}$ によっ てあまり変化しない。そのため、地盤増幅度の $M_{w}$ 依存性が小さ く、 $M_{w}$ の大小によらず地盤増幅度が大きくなる可能性がある。

\section{謝辞}

本論文では独立行政法人 防災科学技術研究所の KiK-net の観測 記録を使用させて頂きました。また、查読者の方々から貴重なご意 見を頂きました。記して御礼申し上げます。

\section{参考文献}

1) 翠川三郎, 松岡昌志, 作川孝一: 1987 年千葉県東方沖地震の最大加速度 . 最大速度にみられる地盤特性の評価, 日本建築学会構造系論文報告集, No.442, pp.71-78, 1992.12

2）大西淳一, 山崎文雄，若松加寿江 : 気象庁地震記録の距離減衰式に基つ く地点增幅特性と地形分類との関係, 土木学会論文集, No.626, pp.79-91, 1999.7

3) 大野 晋, 高橋克也, 源栄正人：カリフォルニア強震記録に基づく水平 動・上下動の距離減衰式と日本の内陸地震人の適用, 日本建築学会構造 系論文集，No.544，pp.39-46，2001.6

4) 内山泰生, 翠川三郎：地震記録および非線形応答解析を用いた地盤分類 別の地盤増幅率の評価, 日本建築学会構造系論文集, No.571, pp. 87-93, 2003.9

5）川瀬 博，松尾秀典：K-NET，KiK-net，JMA 震度計観測網による強震 動波形を用いた震源・パス・サイト各特性の分離解析, 日本地震工学会 論文集，Vol. 4，No. 1，pp.33-52，2004.2

6) 藤本一雄，翠川三郎：近接観測点ペアの強震記録に基づく地盤増幅度と 地盤の平均 $\mathrm{S}$ 波速度の関係, 日本地震工学会論文集, Vol.6, No.1, pp.11-22, 2006.2

7) Kanno, T., Narita, A., Morikawa, N., Fujiwara, H. and Fukushima, Y. A new attenuation relation for strong ground motion in Japan based on recorded data, Bull. Seism. Soc. Am., Vol.96, pp.879-897, 2006.6

8) 藤川 智, 杉戸真太 : 振幅依存型の地盤増幅度の評価法, 土木学会論文集 A1，Vol. 67, No. 2, pp.272-282，2011.6 
9) 佐藤智美, 大川 出, 西川孝夫, 佐藤俊明 : 長周期応答スペクトルの地盤 増幅率の経験的予測式とその理論的解釈, 日本建築学会構造系論文集, No.669, pp.1905-1914, 2011.11

10) 片岡俊一, 山本博昭 : 地震動記録に基づく青森県内の強震観測点のサイ 卜増幅度, 日本地震工学会論文集, Vol. 7, No. 2 (特集号), pp.110-129, 2007.3

11) 紺野克昭, 鈴木貴博, 鎌田泰広, 長尾 毅 : 横浜市高密度強震ネットワ 一ク観測点における微動を用いた地盤の平均 $\mathrm{S}$ 波速度の推定, 土木学会 論文集 A, Vol. 63, No. 4, pp.639-654, 2007.10

12) 翠川三郎, 駒澤真人, 三浦弘之：横浜市高密度強震計ネットワークの記 録に基づく地盤増幅度と地盤の平均 $\mathrm{S}$ 波速度との関係, 日本地震工学会 論文集，Vol. 8， No. 3，pp.19-30，2008.8

13) 神田克久, 武村雅之: 震度データから推察される相模卜ラフ沿いの巨大 地震の震源過程, 日本地震工学会論文集, Vol. 7, No. 2 (特集号), pp.68-79, 2007.3

14）西川隼人, 宮島昌克：地震規模依存性を考慮した地盤増幅度評価式の改 良と観測増幅度との比較, 日本地震工学会論文集, Vol. 12, No. 3, pp.34-48, 2012.8

15) 西川隼人, 宮島昌克 : 地震動スペクトルのパラメータによる地盤増幅度 の表現と地震規模依存性の評価, 土木学会論文集 $\mathrm{A} 1$ (構造・地震工学), Vol. 66, No.1, pp.20-29, 2010.7

16) 独立行政法人 原子力安全基盤機構: 平成 16 年度原子力発電立地調査に 関する報告書(地震波伝ぱ特性評価法調査)，2005.9

17) 独立行政法人 原子力安全基盤機構: 平成 18 年度原子力施設等の耐震性 評価技術に関する試験及び調査 活断層及び地震動特性に関する調査・ 解析に係る報告書, 2007.7

18）日本原子力発電株式会社，独立行政法人日本原子力研究開発機構，関西 電力株式会社 : 若狭地域の地震動評価に用いる地盤モデル再評価につい て【補足検討】, 総合資源エネルギー調査会原子力安全・保安部会耐震・
構造設計小委員会，地震・津波、地質・地盤合同 WG（第 42 回）, 2010.1 19) 木下繁夫，大池美保 : 関東地域の堆積層-基盤系における $\mathrm{S}$ 波の減衰特性 $-0.5 \sim 16 \mathrm{~Hz}-$ ，地震第 2 輯, Vol.55, pp.19-31，2002.7

20) 独立行政法人防災科学技術研究所広带域地震観測網 F-net, http://www.fnet.bosai.go.jp/, 2013.1.25 参照

21) 川上洋介, 纐纈一起, 久田嘉章 : 地震観測記録より推定した関東平野に おけるサイト特性と地形分類との関係, 日本建築学会大会学術講演梗概 集, B-2, pp.687-688, 2004.8

22) Boore, D. M. : Stochastic simulation of high-frequency ground motions based on seismological models of the radiated spectra, Bull. Seism. Soc. Am. 73, pp.1865-1894, 1983.12

23) Hanks, T., and Kanamori, H. : A moment magnitude scale, J. Geophys. Res., Vol.84, No. B5, pp.2348-2350, 1979.5

24) Boore, D. M. and J. Boatwright : Average body-wave radiation coefficients, Bull. Seism. Soc. Am. Vol.74, pp.1615-1621, 1984.10

25) Takemura, M., T. Ikeura, and T. Uetake: Characteristics of source spectra of moderate earthquakes in a subduction zone along the pacific coast of the southern Tohoku district, Japan, J. Phys. Earth, Vol.41, pp.1-19, 1993

26) Faccioli, E. : A study of strong motions from Italy and Yugoslavia in terms of gross source properties, Geophysical Monograph, 37, Maurice Ewing, AGU, Vol.6, pp.297-309, 1986.1

27) 佐藤智美: 統計的グリーン関数の最大加速度・最大速度の距離減衰特性, 日本地震工学会論文集, Vol. 7, No.6, pp.1-16, 2007.8

28) 気象庁：震度を知る 基礎知識とその活用，53p，ぎょうせい， 1996

（2013年 7 月 7 日原稿受理，2014年 1 月 8 日採用決定） 